Research, part of a Special Feature on The Energy-Water Nexus

\title{
Underground Thermal Energy Storage: Environmental Risks and Policy Developments in the Netherlands and European Union
}

\author{
Matthijs Bonte $^{1}$ Pieter J. Stuyfzand $^{1}$, Adriana Hulsmann ${ }^{1}$, and $\underline{\text { Patrick Van Beelen }}^{2}$
}

\begin{abstract}
We present an overview of the risks that underground thermal energy storage (UTES) can impose on the groundwater system, drinking water production, and the subsurface environment in general. We describe existing policy and licensing arrangements for UTES in the Netherlands, as well as the capability of the current and future Dutch policy and legal framework to minimize or mitigate risks from UTES on groundwater resources. A survey at the European Union member state level indicates that regulation and research on the potential impacts of UTES on groundwater resources and the subsurface environment often lag behind the technological development of and ever-growing demand for this renewable energy source. The lack of a clear and scientifically underpinned risk management strategy implies that potentially unwanted risks might be taken at vulnerable locations such as near well fields used for drinking water production, whereas at other sites, the application of UTES is avoided without proper reasons. This means that the sustainability of UTES as a form of renewable energy is currently not fully understood, and the technology may be compromising the natural resilience of the subsurface environment. We recognize three main issues that should be addressed to secure sustainable application of UTES: Scientific research is required to further elucidate the impacts of UTES on groundwater; cross-sectoral subsurface planning is required to minimize negative conflicts between UTES and other subsurface interests; and EU-wide guidelines and standards are required for quality assurance and control when installing UTES systems.
\end{abstract}

Key Words: ground source heat pumps; groundwater; groundwater quality; underground planning; underground thermal energy storage

\section{INTRODUCTION}

In 2008, the European Union agreed on an ambitious plan to combat climate change and promote renewable energy. The plan's aim is to transform Europe to a low-carbon economy and increase its energy security. With this plan, the EU commits to reduce its overall carbon emissions to at least $20 \%$ below 1990 levels by 2020; the EU is willing to scale up this reduction to as much as $30 \%$ under a new global climate change agreement when other developed countries make comparable efforts. Recently, a new private initiative called 10:10 was started in the United Kingdom by individuals who are worried that policymakers are not moving quickly enough to combat climate change. Under the 10:10 initiative, individuals, schools, hospitals, businesses, and organizations are urged to take action to combat climate change and cut their emissions by $10 \%$ in 2010 . The movement aims to put pressure on politicians to cut emissions as quickly as the science demands.

Underground thermal energy storage (UTES) is used for heating and cooling purposes in the built environment and is considered to be a technology that can significantly contribute to the reduction of greenhouse gas emissions. In the Netherlands, two types of UTES systems are used: open and closed systems. Open systems, also called aquifer thermal energy storage (ATES) or open-loop ground source heat pumps, use groundwater to store heat. These systems generally operate with one or more extraction and injection wells to circulate groundwater. During summer, heat is transferred from buildings to the groundwater, which increases the groundwater temperature. In Dutch systems, the natural groundwater temperature is typically 
Fig. 1. Development of aquifer thermal energy storage (ATES) systems and borehole thermal energy system (BTES) wells in the Netherlands. ATES data were sourced from provincial authorities; BTES data are from Centraal Bureau voor de Statistiek (2008).
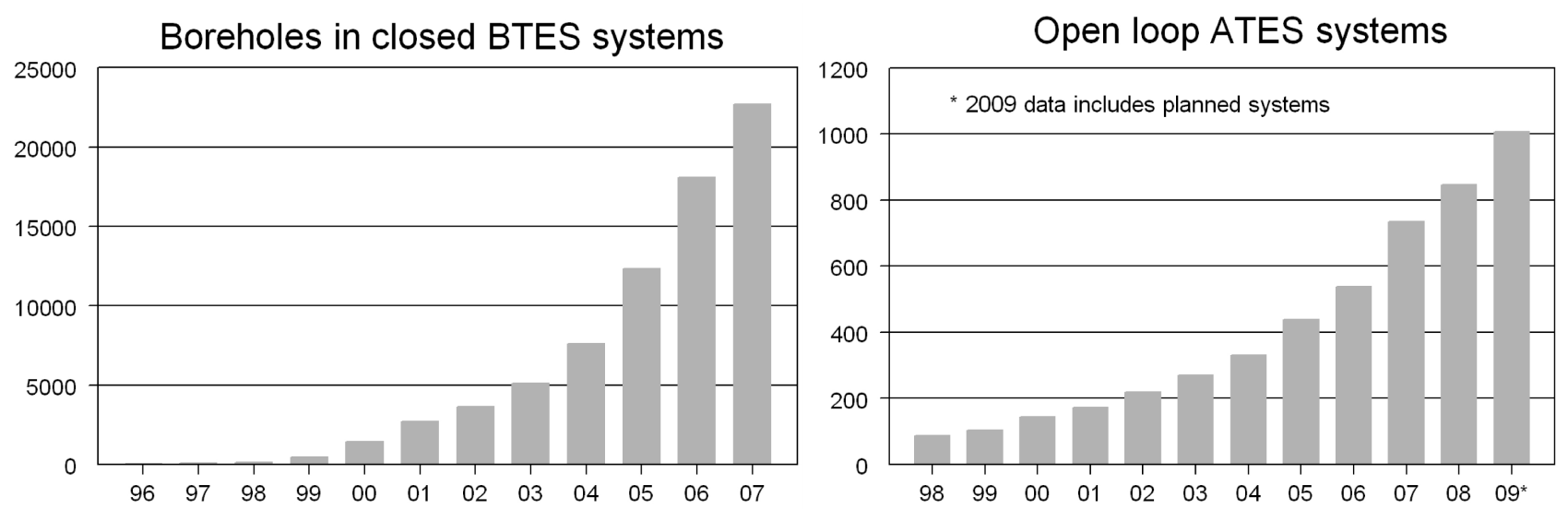

increased from $9-12^{\circ} \mathrm{C}$ to $15-20^{\circ} \mathrm{C}$. During winter, the system extracts the relatively warm groundwater and uses it to heat buildings. This involves cooling the groundwater, typically back to values ranging between 5 and $10^{\circ} \mathrm{C}$. Closed systems, also called borehole thermal energy systems (BTES), use plastic conductor pipes and one or more boreholes (vertical closed systems) or trenches (horizontal closed systems). A coolant fluid extracts heat from underground, and no groundwater is used during the process. These systems generally operate with more extreme temperatures compared to ATES systems.

The number of ATES and BTES systems installed has increased over the last decade (Fig. 1). The number of ATES systems increased from approximately 100 in 1999 to nearly 1000 in 2009. According to licensing data, approximately 350 million $\mathrm{m}^{3} / \mathrm{yr}$ of groundwater is used. This water volume is quite considerable compared to the total annual groundwater extraction in the Netherlands of approximately 1500 million $\mathrm{m}^{3} / \mathrm{yr}$ (De Vries

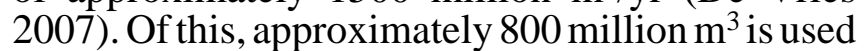
for drinking water, 300 million $\mathrm{m}^{3}$ for industrial water use, and 400 million $\mathrm{m}^{3}$ for agricultural use. The total annual groundwater recharge in the Netherlands is estimated to be approximately 9000 million $\mathrm{m}^{3} / \mathrm{yr}$ (Dufour 2000). Although ATES does not extract a net amount of groundwater because the water is returned to the aquifer, groundwater flow patterns and the quality of the groundwater can be influenced by ATES systems.

The number of BTES systems installed is even larger than that of ATES systems. The Dutch national statistical institute estimates that the number of BTES boreholes has grown from 24 in 1996 to approximately 18,000 in 2006 (Centraal Bureau voor de Statistiek 2008). These numbers are based on very rough estimates because permits to install BTES systems are currently not required in most cases, and there is no central registration of drilled BTES wells. Similar strong growth rates are reported in other European countries such as Switzerland, Sweden, and Germany (Sanner et al. 2003), as well as in China (Gao et al. 2009).

Given the accelerating installation rate for UTES systems in the Netherlands and Europe and the ambitions of the Dutch government in this field, more UTES systems are expected to be installed near public water supply well fields (PWSWFs). This is illustrated by the locations of ATES sites in the province of Noord Brabant (surface area of 5082 $\mathrm{km}^{2}$ ) in the south of the Netherlands in relation to PWSWFs groundwater protection zones (Fig. 2). The risks of UTES (both ATES and BTES systems) to groundwater quality are insufficiently known, 
Fig. 2. Map showing the locations of aquifer thermal energy storage (ATES) systems and groundwater protection zones for public supply well fields in the province of Noord-Brabant, the Netherlands. ATES data were sourced from provincial authorities; groundwater protection zones data are courtesy of the National Institute for Public Health and the Environment.

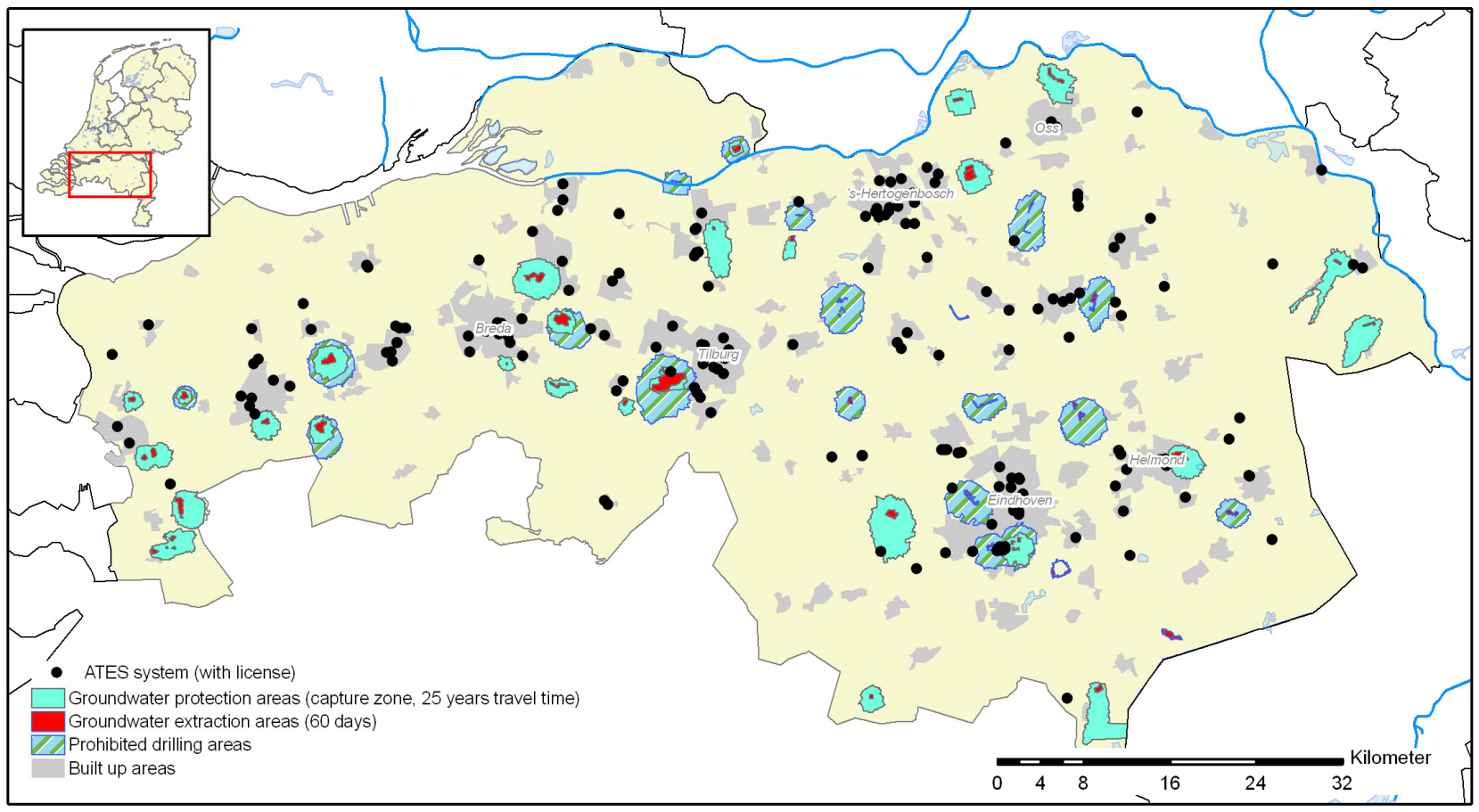

and policies to address this uncertainty are still lacking.

The main question we address here is whether Dutch and other EU national governments are ready to regulate the increasing use of UTES while minimizing potentially adverse effects on the underground environment. We first detail the risks that UTES may impose on groundwater quality and drinking water production. We then describe current and future policy and licensing arrangements for UTES in the Netherlands and the EU. Finally, we discuss the need for cross-sectoral subsurface spatial planning to minimize negative effects from various subsurface activities. This will result in valuable lessons for other countries in shaping policy on groundwater protection and UTES.

\section{ENVIRONMENTAL IMPACTS AND INTERFERENCE WITH OTHER SUBSURFACE INTERESTS}

To assess the risks from UTES systems to groundwater quality and ecology and drinking water production, we reviewed common practices in UTES operation in relation to drinking water production (Bonte et al. 2008). From this review, four groups of environmental risks arising from UTES were distinguished: hydrological, thermal, chemical, and microbiological (Table 1). Some effects have a small probability of occurrence but have potentially far-reaching consequences, e.g., leaching and leaking of heavy metals or antifreeze medium; they therefore have high associated risk. Other effects are certain to occur, but with minor consequences. 
Table 1. Qualitative overview of risks of low-temperature $\left(<30^{\circ} \mathrm{C}\right)$ underground thermal energy storage on groundwater systems.

\begin{tabular}{|c|c|c|}
\hline $\begin{array}{l}\text { Negative effect of underground thermal } \\
\text { energy storage }\end{array}$ & Probability $^{\dagger}$ & Consequence $^{\ddagger}$ \\
\hline
\end{tabular}

\section{Hydrological impacts}

Changing water levels and fluxes

Changing other well's capture zone

Poorly sealed boreholes

\section{Thermal impacts}

Changing water temperature

\section{Chemical impacts}

Mixing processes and chemical reactions

Reactivation of otherwise stable groundwater pollution plumes

Oxidation of organic matter

Oxidation of iron sulfides

Dissolution/precipitation of carbonates

Dissolution/precipitation of silicates

Leaching from installation materials

Leaking anti-freeze fluids or additives

\section{Microbiological impacts}

Introduction or mobilization of pathogens

Increasing biodegradation rate

Changing microbiological population

$\begin{array}{ccc}++ & \text { Desiccation, water logging, settlements } & \pm \\ ++ & \text { Increasing vulnerability, pollution } & ++ \\ + & \text { Cross-aquifer flow } & ++\end{array}$

$++\quad$ Temperature, reaction kinetics $\quad+$

\begin{tabular}{ccc}
++ & Salinity, IMIPO, OMIPO & ++ \\
\pm & IMIPO, OMIPO & ++ \\
\pm & Nutrients, DOC, color & + \\
- & $\mathrm{Fe}, \mathrm{SO}_{4}, \mathrm{As}, \mathrm{Ni}, \mathrm{Co}, \mathrm{Zn}$ & \pm \\
- & $\mathrm{Ca}, \mathrm{HCO}_{3}, \mathrm{Sr}$ & \pm \\
\pm & $\mathrm{SiO}_{2}$ & + \\
\pm & $\mathrm{Cd}, \mathrm{Cu}, \mathrm{Cr}, \mathrm{Ni}, \mathrm{Pb}, \mathrm{VC}$ & ++ \\
\hline & Glycol, biocides, corrosion inhibitors & \pm \\
\pm & Pathogens & $?$
\end{tabular}

${ }^{\dagger}$ Probability of occurrence is small $(-)$, moderate $( \pm)$, high $(+)$, or almost always $(++)$.

IIMIPO = inorganic micro-pollutants, OMIPO = organic micro-pollutants, DOC $=$ dissolved organic carbon, $\mathrm{VC}=$ vinyl chloride.

\$Probability of risk is negative, resulting in opportunity $(-)$; none $( \pm)$; low $(+)$, high $(++)$. 


\section{Hydrological impacts}

Hydrological risks are related to aspects of groundwater quantity and include groundwater levels, flow velocities, and the capture zone of PWSWFs. Although ATES systems have no net extraction because groundwater is injected back into the aquifer from which it was extracted, perturbations in the groundwater flow pattern can be noticeable up to a distance of several kilometers (Ferguson 2006). This situation can have a direct impact on the size and location of the capture zone of a groundwater well (Fig. 3). A typical groundwater extraction well has a capture zone and a legally enforced groundwater protection zone, which is usually the area through which the travel time of groundwater to the well is $<25$ years (Fig. 3A). An ATES system can affect the groundwater flow paths of the extraction well, and the alternating extractions and injections will cause the flow paths to become jagged and the capture zone to increase slightly (Fig. 3B). If one well of the ATES is within the capture zone of the extraction well, the ATES system periodically takes groundwater from outside the original capture zone of the extraction well and injects it inside the capture zone (Fig. 3C). This implies that the capture zone of the extraction well is enlarged with the capture zone of the ATES system.

Depending on aquifer conditions such as heterogeneity, reactivity, and land use, this enlargement may cause quality changes at the groundwater extraction well. If surface waters are present within the capture zone, an ATES may alter the nature of groundwater-surface water interactions. For example, a normally gaining stream (receiving groundwater) may change into an alternating losing and gaining stream depending on ATES operation. It should be noted that although capture zones in spatial planning are often considered a steady state feature, in reality, the location will vary because of the transient nature of groundwater recharge and surface water-groundwater interactions (Rock and Kupfersberger 2002). The effect of transient pumping at an ATES system can act cumulatively and exacerbate this variation.

Groundwater flow patterns may also be influenced by poorly constructed ATES or BTES boreholes. Boreholes that lack adequate clay (frequently bentonite) or grout plugs to separate aquifers or boreholes screened in several aquifers may provide preferential flow paths for contaminants or crossaquifer flow (Avci 1992, Lacombe et al. 1995, Chesnaux et al. 2006, Santi et al. 2006, Mayo 2010). Minimizing drilling costs is likely to result in selecting a drilling method that does not allow precise logging of the subsoil to determine the depth of aquitards to be plugged. In the Netherlands, this case is exacerbated when dealing with BTES wells because work is carried out without having to obtain a license. In some countries, regulators enforce the annulus of BTES wells to be grouted to increase the thermal efficiency of the well and reduce the risk of cross contamination. Although cementing may initially limit vertical flow in the borehole, debonding of conductor pipe and grout because of differences in thermal expansion behavior may still result in preferential flow paths later (Philippacopoulos and Berndt 2001). Enhanced grout types, which contain a superplasticizer and bentonite, can reduce the likelihood of debonding (Philippacopoulos and Berndt 2001).

\section{Thermal impacts}

An inventory of 67 ATES systems showed that almost none of the investigated systems had a thermal balance (IF Technology 2007), meaning that cold or heat is discharged into the aquifer and long-term cooling or warming of groundwater is occurring. A study in Winnipeg, Canada, showed that using the aquifer solely for cooling purposes is not sustainable because of long-term rising groundwater temperatures (Ferguson and Woodbury 2006). Apart from reduced efficiency of UTES because of changing temperatures, downstream users of groundwater and aqueous ecosystems can be negatively affected (Ferguson 2009). To assess the long-term cumulative effects of heat discharge adequately, the autonomous trends caused by changing environmental stresses to the groundwater system should also be considered. For example, when analyzing the thermal impacts of UTES on the underground, the temperature effects of climate change and urbanization on the aquifer system should also be taken into account (Taniguchi and Uemura 2005, Ferguson and Woodbury 2007, Kooi 2008). The key question is: Can the effects of UTES be neglected compared to these stresses or should UTES be considered yet another thermal stress on a system that is already threatened? 
Fig. 3. Conceptual illustration of the effects of an aquifer thermal energy storage (ATES) system: alone (A), just outside the capture zone of a public supply well (B), and just inside the capture zone of a public supply well (C). Arrows indicate the path of groundwater flow; red and blue circles are the hot and cold wells, respectively, of an ATES system.

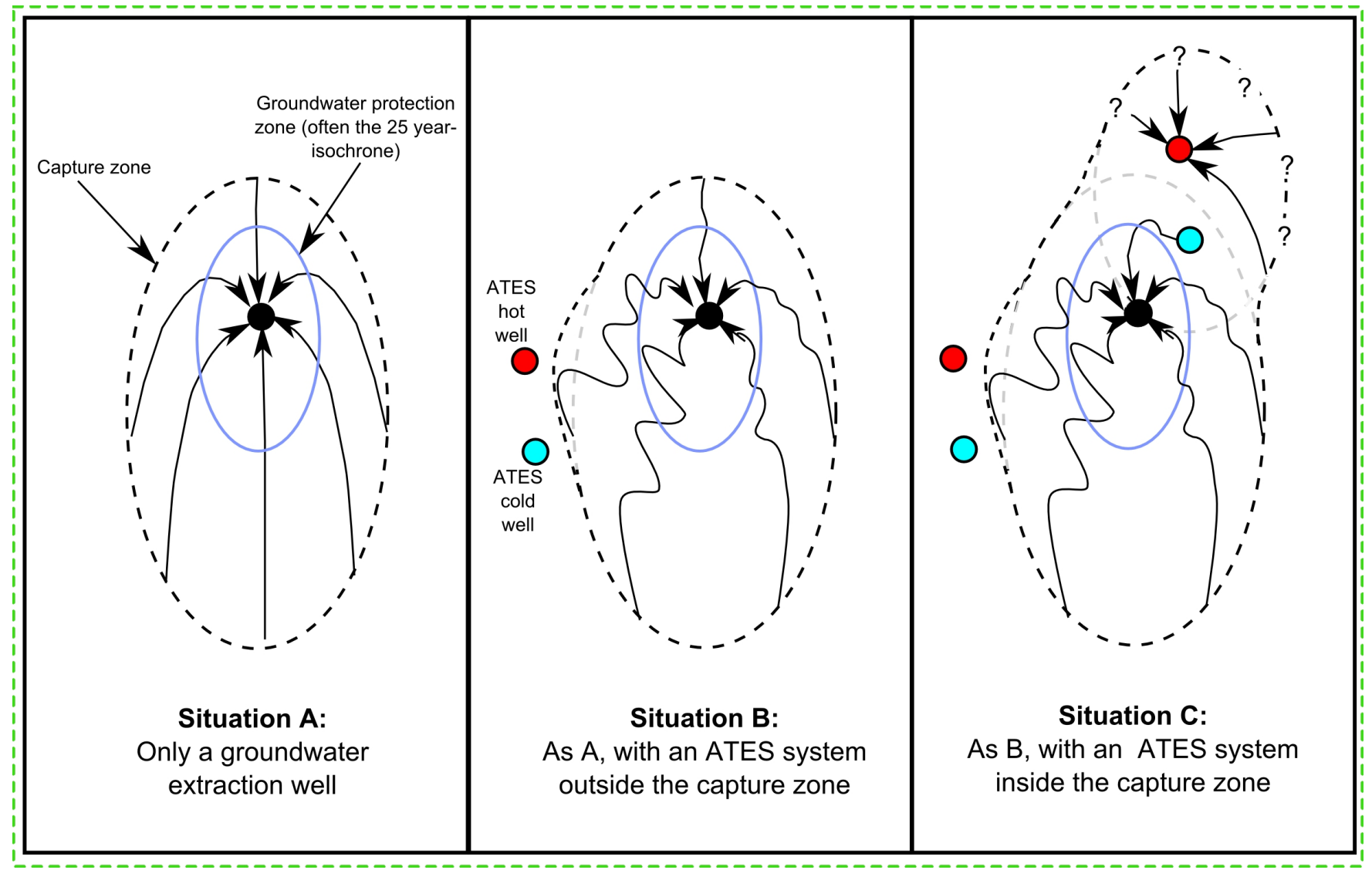

\section{Chemical impacts}

ATES systems may influence groundwater chemistry by the mixing of different types of groundwater, for example, aerobic and anoxic; by mobilizing groundwater contaminants present in many urban areas that are relatively immobile under natural conditions, for example, heavy metals or hydrocarbons; or by changing the thermal regime of the water. Most of the published research on chemical impacts focuses on changes in mineral solubility, reaction kinetics, and organic matter oxidation (Holm et al. 1987, Brons et al. 1991, Griffioen and Appelo 1993, Hoyer et al. 1994, Arning et al. 2006). The results of these studies suggest that these processes will play a significant role at temperatures $>30^{\circ} \mathrm{C}$. However, a seasonal temperature increase from 5 to $15^{\circ} \mathrm{C}$ strongly accelerated pyrite oxidation in a deep well injection experiment in which oxic water was injected in an anoxic aquifer (Stuyfzand 1998, Prommer and Stuyfzand 2005), illustrating that redox reactions, in particular, can be influenced by small temperature changes.

In water table aquifers, groundwater quality varies with depth because of chemical reactions between infiltrating rainwater and reactive soil and aquifer compounds such as carbonates, pyrite, and organic carbon (Stuyfzand 1999, Appelo and Postma 2005). This results in a vertical groundwater quality gradient with oxidized, nitrate-rich, shallow 
groundwater and reduced, iron-rich, deeper groundwater. The aquifer acts as a groundwater quality buffer and assures stable and relatively high quality compared to, for example, that of surface water. An ATES system extracts groundwater from a certain depth interval, mixes it, and reinjects the mixture into the aquifer (Bonte et al. 2011), homogenizing the natural vertical quality gradient. This can have adverse effects for the quality of the groundwater resource, introduce environmental pollutants to greater depths in the aquifer, and minimize the volume of clean uncontaminated groundwater, ultimately increasing the vulnerability of PWSWFs or extraction wells for other purposes.

In the Netherlands, ATES is often used in urban aquifers that have been contaminated by previous activities and uses such as chemical dry cleaning, oil storage tanks, and gasworks. The effect of ATES on groundwater contamination plumes is still unclear. Increased groundwater temperature may mobilize otherwise immobile contaminants by increasing solubility and reducing sorption (Knauss and Copenhaver 1995, ten Hulscher and Cornelissen 1996, Knauss et al. 2000) or may increase contaminant toxicity (Noyes et al. 2009). However, mixing of different chemical groundwater types, mobilization of nutrients, and increased groundwater temperature may accelerate biodegradation (Langwaldt and Puhakka 2000). In the Dutch cities of Eindhoven, Apeldoorn, and Utrecht, field and feasibility studies are currently being conducted to combine ATES with a groundwater remediation system (Slenders et al. 2010).

BTES systems use cooling fluids that, in the case of a poorly installed, damaged, or aged system, can leak into the aquifer. The coolant is often a mixture of an antifreeze agent such as glycol, a biocide, and a corrosion inhibitor (Klotzbüicher et al. 2007). Although both aerobic and anaerobic biodegradation has been observed in soils for frequently used antifreeze agents such as ethylene glycol, propylene glycol, and betaine, the addition of corrosion inhibitors or biocides in BTES systems can inhibit biodegradation (Klotzbücher et al. 2007). The prevalence of contaminant release from leaky UTES systems is currently not known. However, given the growing number of BTES systems in the Netherlands alone and the lack of regulations to enforce the quality drilling work, the risk of groundwater system contamination is likely to increase.

\section{Microbiological impacts}

The microbial quality of groundwater is a vulnerable and valuable asset, especially when groundwater is used as a source for tap water. Groundwater is not a sterile environment, but rather an ecosystem, and even anaerobic groundwater contains bacteria (Griebler and Lueders 2009). Fungi, protozoa, and animals are also present in aerobic groundwater (Goldscheider et al. 2006). Many geochemical processes are in fact catalyzed by bacteria (Appelo and Postma 2005), such as the oxidation of $\mathrm{Fe}^{2+}$ to $\mathrm{Fe}^{3+}$, in which bacteria obtain energy for growth from the geochemical process. Groundwater microorganisms oxidize the nutrients present and lower the redox potential (Korom 1992); this nutrient removal is important for groundwater quality because it prevents the growth of pathogens in groundwater and in drinking water infrastructure.

Because there are many different types of pathogens, it is very difficult to prove that they are absent from drinking water. Different people have different susceptibilities for pathogens, and a minority of the population might become ill for a certain period because of pathogens in drinking water. Standard tests for fecal bacteria in water are effective in detecting fecal pollution but are not proof that there are no pathogens in the water samples (Winters, unpublished manuscript).

To date, there is little information about the risks of UTES for the microbial communities in groundwater. Microbiological impacts by ATES systems can occur because of changing groundwater temperatures (Hall et al. 2008) or the introduction of biologically available nutrients by well drilling fluids. Previous microbiological research on UTES systems showed that although there is no evidence for growth of pathogens (Winters, unpublished manuscript: http://www.osti.gov/energycitations/se rvlets/purl/10122061-fHeD14/10122061.pdf) or increasing cell counts (Schippers and Reichling 2006), there is a considerable change in the bacterial community composition (Brielmann et al. 2009; L. Sowers, K. P. York, and L. Stiles, unpublished manuscript: http://intraweb.stockton.edu/eyos/ener gy studies/content/docs/FINAL PRESENTATION S/4A-5.pdf). When these altered microbial communities contain relatively high numbers of microbes, they might pose a risk for the preparation of drinking water from groundwater from these locations. This reinforces the necessity to have 
protection zones around drinking water wells that prohibit the use of UTES (Schijven et al. 2006).

\section{CURRENT UNDERGROUND THERMAL ENERGY STORAGE POLICY IN THE NETHERLANDS}

Currently, open-loop ATES systems are required to obtain a permit from the provincial government as enforced in the national Water Act. All 12 Dutch provinces have developed their own policy guidelines for permitting ATES systems, and no overarching national policy on the implementation of ATES exists. As a result, there are considerable differences in policy across provinces. In general, ATES systems are not allowed in groundwater protection areas for drinking water supply.

Policy differences between provinces with regard to ATES systems can be considerable. For example, the province of Zuid-Holland prohibits the use of the first (or most shallow) aquifer for ATES systems in urban and greenhouse areas. This exclusion aims to minimize conflicts with other subsurface uses such as underground construction (e.g., parking garages) in urban areas and subsurface rainwater storage in greenhouse areas. As a result, ATES systems can only be realized in the deeper (second and third) aquifers, causing small ATES systems often to be not financially viable because of high drilling costs. In contrast, the province of NoordBrabant has prohibited ATES systems to be installed deeper than $80 \mathrm{~m}$ in an effort to protect the quality of the deep fresh groundwater used for the drinking water supply. Whether this is a sensible strategy is questionable. ATES systems installed in the phreatic aquifer can adversely affect groundwater quality and introduce pollutants normally restricted to shallow groundwater into deeper aquifer layers.

Currently, closed systems are regulated only in groundwater protection zones under the national Environmental Protection Act. The provinces have set further environmental regulations in these zones for BTES systems via provincial environmental regulations. In all provinces, drilling or disturbing the soil below $2-3 \mathrm{~m}$ is prohibited in groundwater protection zones, except when an exemption has been obtained; exemptions are not granted in most cases. Outside groundwater protection zones, BTES systems can be installed without registration or license. There are two loopholes in the regulations inside groundwater protection zones. The first is to use a horizontal closed system that remains $<2 \mathrm{~m}$ in depth. The second occurs if provincial authorities have delegated the enforcement of provincial environmental regulations to the municipalities. Municipalities are often heavily involved in urban developments and may even be the initiators for the installation of BTES systems. If a municipality is both initiator and regulator, it is questionable whether the different interests in the display subsurface, i.e., groundwater protection versus renewable energy production, are weighed sensibly because there is a clear conflict of interest between the two.

\section{UNDERGROUND THERMAL ENERGY STORAGE POLICY CHANGES IN THE NETHERLANDS}

In 2008, the Dutch Ministry of Housing, Spatial Planning, and the Environment commissioned a group of energy, soil, and water experts to draft a plan to stimulate deployment of UTES while considering the potential risks that this technology holds for groundwater and soil quality. The report contains a number of recommendations (Taskforce WKO 2009). The most important recommendations are policy changes, including: a so-called "traffic light model" for UTES permits, the introduction of subsurface spatial planning, and a proper distribution of the financial costs and benefits for large-scale UTES development.

The first recommendation involves a geographical distinction of three zones for all types of UTES deployment, i.e., the "traffic light model". In green areas, UTES can be used without a permit. In orange areas, other subsurface interests exist, such as existing UTES systems, and a permit is required. In red areas, other, often more important, subsurface interests exist, such as drinking water production, and only under special circumstances is a permit granted. It is unclear which government level (municipal, provincial, or national) will be primarily responsible for the recommendation's implementation. A similar approach has been applied successfully in Germany (W. J. Eugster and B. Sanner, unpublished manuscript: http://www.egec.org/target/final\%20paper\% 20ShallowGeothermal.pdf).

The second recommendation involves a more important role for municipalities in subsurface spatial planning, especially in areas defined as 
orange and red in the traffic light model. In dense urban areas such as The Hague or Rotterdam, available underground space is rapidly decreasing. Poorly positioned UTES systems can negatively affect each other, causing reduced overall efficiency. Such issues need to be addressed by future subsurface planning. In some cities in the Netherlands, subsurface master plans are developed in which the exploitation of the underground for UTES is regulated. An example is a subsurface planning map that shows regions where cold and warm wells for ATES systems can be installed (Fig. 4; Witteveen+Bos 2008). Similar efforts for subsurface master planning dealing with the growing use of the subsurface have been addressed recently in the scientific literature (Uršej and Kontic 2007, Bobylev 2009, Evans et al. 2009).

The third recommendation relates to the fact that UTES is being developed increasingly by energy suppliers and project developers at the scale of suburbs or large housing blocks. The end user is legally bound to purchase heat from the owner of the UTES system to guarantee that energy delivered by the system is used. If this is not guaranteed, many large-scale initiatives may become financially nonviable because the risk of having an under-used system may not be acceptable for private investors. The National Heat Act regulates the price that private investors can ask on the principle that the cost for heat obtained from heat delivery systems such as UTES should not exceed the cost for heat when using a conventional gas heater. However, the owner of an individual conventional gas heater can currently choose from a dozen different energy suppliers and negotiate an attractive price. Two issues arise as a result of this pricing system. First, prices charged for using UTES systems are, in reality, often higher than when using conventional gas heaters because gas prices are subject to free market forces. Second, UTES is, in most cases, far more cost-effective than conventional heating with the return on investment period for the start-up cost of a UTES system for an office building in the Netherlands, typically ranging between 5 and 10 years. Thus, the end user of the UTES system often does not receive the financial benefits of the system, and UTES brings a new and attractive business for the project developers and energy suppliers.

Under the proposed policy changes, the Underground Energy Taskforce expects that a growth rate of approximately $30 \% / y r$ can be achieved for UTES deployment. The Underground
Energy Taskforce estimates that without policy changes, the autonomous growth rate will be approximately $12 \% / y r$. These two scenarios yield a total of 18,000 or 3500 ATES systems in operation in 2020, under the altered or current UTES policies, respectively. This in turn results in $\mathrm{CO}_{2}$ emissions reductions of 0.6 to $2.9 \mathrm{Mton} / \mathrm{yr}$ for the two scenarios. The total $\mathrm{CO}_{2}$ emissions in the Netherlands is estimated by the Centraal Bureau voor de Statistiek (2008) at 173 Mton in 2007, of which approximately $40 \%$ (70 Mton) is generated in the built environment. No figures are given by the Taskforce on the volume of groundwater used. If we assume a water use per system that is equal to the current situation, the total water use in 2020 will be 1225 to 6300 million $\mathrm{m}^{3} / \mathrm{yr}$, depending on the scenario. With total annual groundwater extraction of 1500 million $\mathrm{m}^{3} / \mathrm{yr}$ and total annual groundwater recharge of 9000 million $\mathrm{m}^{3} / \mathrm{yr}$, this means that the production of renewable energy is likely to be the largest user of groundwater in the Netherlands in 2020.

\section{POLICIES OF EUROPEAN MEMBER STATES ON UNDERGROUND THERMAL ENERGY STORAGE}

UTES systems are widespread in Europe, with a long history in central Europe (Austria, Germany, and Switzerland) and Sweden. Next, a market developed in the Benelux countries (France, Finland, Ireland, and United Kingdom) and the eastern European countries. The use of such systems in southern Europe is still in its infancy, but there is strong potential for its implementation because the largest energy savings are realized when using especially ATES for cooling purposes. The current dramatic increase in demand has changed the established market, which has resulted in the involvement of new players with less experience and less training. Strong quality assurance with associated training and certification programs are needed urgently to prevent negative environmental impacts and damage to the public perception of the technology (W. J. Eugster and B. Sanner, unpublished manuscript: http://www.egec.org/target/ final\%20paper\%20ShallowGeothermal.pdf).

In 2009, a first exploratory inventory was made among ENDWARE members (ENDWARE is the informal European Network of Drinking Water Regulators). Questions were asked about the penetration level of UTES within the national 
Fig. 4. Subsurface spatial planning map for the second aquifer in the Goudse Poort in Gouda, the Netherlands. Red, blue, and grey regions indicate areas where hot, cold, and no aquifer thermal energy storage wells, respectively, can be installed. Modified from Witteveen+Bos (2008).
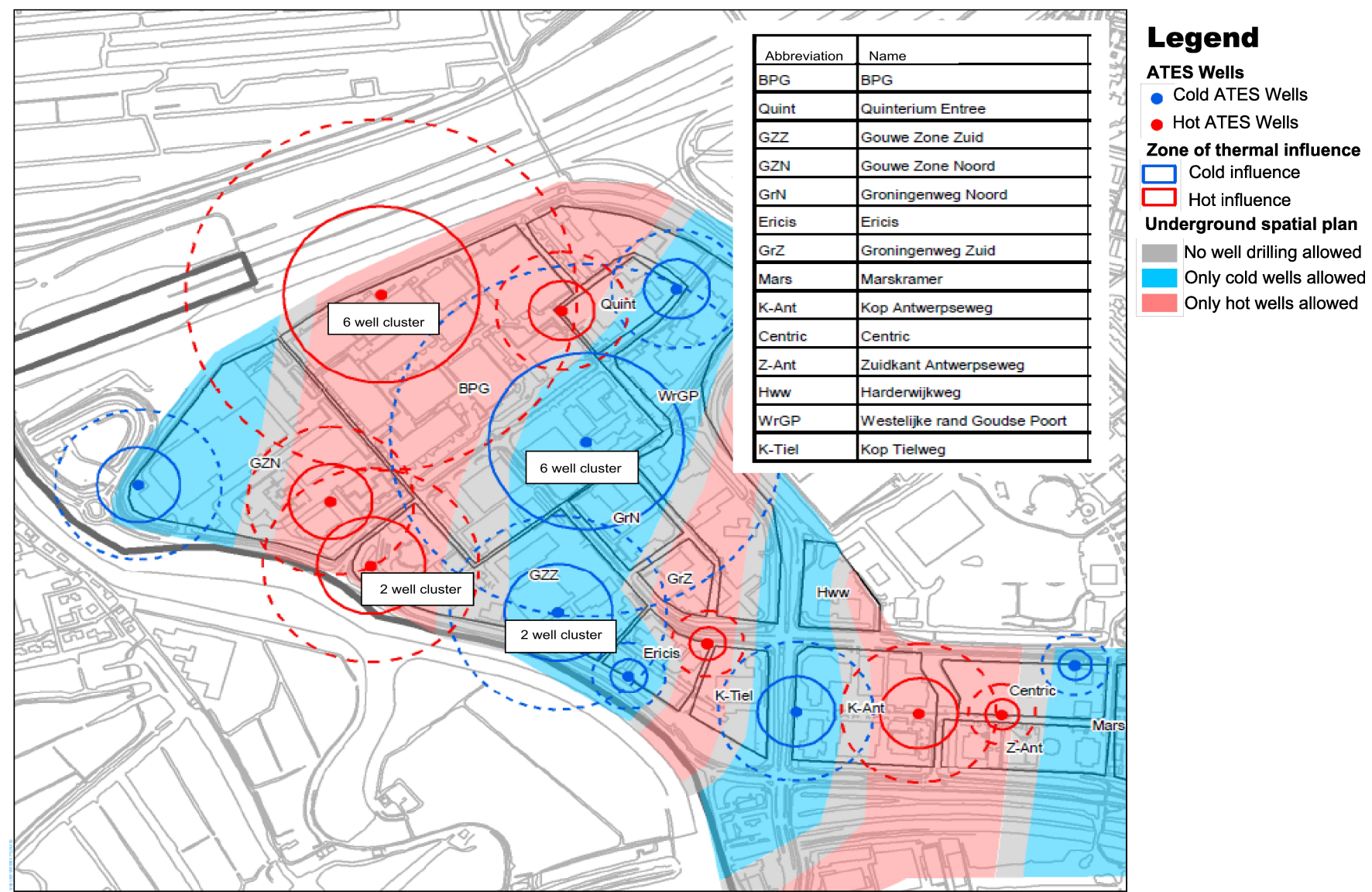

territory, whether or not regulators had considered the potential impacts on underground water resources, and the availability of existing or scheduled policy and regulation of underground systems within and outside groundwater protection zones. EU member states such as Germany, Sweden, the Netherlands, Poland, Estonia, Lithuania, and the United Kingdom recognized the growing issue of energy-related activities in the underground and the potential risk to groundwater supplies designated for the production of drinking water. Estonia, for example, began drafting legislation in 2009. In Poland, attempts have been made to issue regulations, but there is no clear legislation yet. In Poland, the land-owner has the right to exploit the groundwater without restriction.
ENDWARE members from other EU member states such as Lithuania, Italy, Czech Republic, Portugal, Slovenia, and Cyprus are not aware of any specific requirements or do not know about the technology and related regulation. In Norway, the building of UTES systems is not prohibited, but specifications and environmental protection measures are decided on a case-by-case basis.

Comprehensive regulation is in force in traditional UTES countries such as Sweden, the United Kingdom, Switzerland, Germany, and Austria. The controlled activities regulation system in Scotland allows the Scottish Environmental Protection Agency to control activities that may have an impact 
on the water environment, both groundwater and surface water. It is the key legislation that enables Scotland to achieve environmental improvements and to protect and improve the water environment in a sustainable way in line with the aims and objectives of the EU Water Framework Directive. Sweden not only uses BTES and ATES systems, but also Cavern Thermal Energy Storage (CTES) systems. The regulation for BTES varies among areas of Sweden; for ATES and CTES, the water laws and regulations apply. Furthermore, a standard that regulates borehole construction aims to protect groundwater from contamination. Similar efforts to develop a well drilling guideline are currently being undertaken in the Netherlands.

Within the countries with developed markets, national or regional water management, and/or groundwater protection, authorities have published guidelines for the license proceedings and for the construction and operation of the installations. The German Verein Deutscher Ingenieure VDI-GET (VDI) has developed technical guidelines for the thermal use of the underground, compiling environmental aspects, basic requirements of components, and installation techniques (M. Reuss, E. Konstantinidou, and B. Sanner, unpublished manuscript: http://intraweb.stockton.edu/eyos/ener gy studies/content/docs/FINAL PAPERS/5A-3.pdf ). The VDI worked with experts from neighboring countries like Switzerland, Austria, and the Netherlands to exchange experiences and harmonize and facilitate international rule making. The VDI documents are also meant to be used as basis documents in the drawing up of European or international rules in harmonization with institutions responsible for these rules (B. Sanner, unpublished manuscript: http://www.sanner-geo.de/ media/iea \$20hpc\$202008\$20sanner\$20standards.pdf ) .

On a more general level, the planning of various underground activities is highly recommended, especially in urban areas. In urban areas, there are four principal underground resources that contribute significantly to the sustainable development of cities: space, water, geothermal energy, and geo-materials. Traditionally, planning of underground works is done on a single-project basis with little consideration of other potential uses. This sectoral approach often produces interference between uses, e.g., road tunnels that interfere with geothermal structures; causes negative environmental impacts, e.g., by groundwater contamination; restricts innovative opportunities for sustainable development, e.g., using waste heat from metro lines to heat buildings (P. Maire, P. Blunier, A. Parriaux, and L. Tacher, unpublished manuscript: http://www.surf.salford.ac.uk/cms/resources/uploads/ File/Going\%20Underground/Pierrick Maire.pdf); and curtails the use of foundation structures for geothermal purposes.

\section{DISCUSSION: SUBSURFACE TECHNOLOGY DEVELOPMENT AND REGULATION}

From our overview of risks and policies relating to UTES, we identify two undesirable developments. First, new technologies are developed by one sector without considering the impacts on other sectors. This not only poses potential threats to groundwater resources and the subsequent drinking water supply, but also generates conflicts with other potential users of the underground (Table 2). This underscores the need for a cross-sectoral approach that balances all interests and the need for the development of master plans indicating all subsurface activities, not only drinking water and UTES. Spatial subsurface planning is required to minimize negative interference or, in some cases, combine individual subsurface activities to achieve greater mutual benefit. The speed of development and implementation of UTES systems has not been matched by the responsible policy makers. This risk has been exacerbated by the need to reduce climate change footprints and for sustainable and financially attractive solutions at all levels.

Regulators need to be aware of the emerging technologies and the activities of first movers on the market. New developments should be considered and weighed for their potential adverse impacts on other stakeholder groups. Policy makers should strive to find a balance between setting unnecessary barriers to the development and implementation of new technology and the protection of important factors such as safety, as well as health and economic interests. Our initial survey of UTES implementation and regulation in the EU shows that many member states are unaware of the activities within their territory or are unfamiliar with the concept. As a result, many countries do not have regulations in place to deal with UTES activities. This is a typical example of a situation in which regulation lags behind development and unforeseen risks on the underground ecosystem and drinking water resources go unchecked. 
Table 2. Matrix indicating interference between various subsurface functions. ${ }^{\dagger}$

\begin{tabular}{|c|c|c|c|c|c|c|c|c|c|c|}
\hline $\begin{array}{l}\text { Subsurface } \\
\text { function }\end{array}$ & ATES $^{\ddagger}$ & BTES $^{\S}$ & $\begin{array}{l}\text { Geother- } \\
\text { mal } \\
\text { energy }\end{array}$ & $\begin{array}{l}\text { Water } \\
\text { supply }\end{array}$ & $\begin{array}{l}\text { Infra- } \\
\text { structure }\end{array}$ & $\begin{array}{c}\text { Shallow } \\
\text { geo- } \\
\text { material }\end{array}$ & $\begin{array}{c}\text { Deep } \\
\text { geo- } \\
\text { material }\end{array}$ & $\begin{array}{l}\mathrm{CO}_{2} \\
\text { storage }\end{array}$ & $\begin{array}{l}\text { Gas } \\
\text { storage }\end{array}$ & $\begin{array}{l}\text { Water } \\
\text { storage }\end{array}$ \\
\hline ATES & \pm & - & + & - & - & + & + & + & + & - \\
\hline BTES & & \pm & + & - & + & + & + & + & + & + \\
\hline $\begin{array}{l}\text { Geothermal } \\
\text { energy }\end{array}$ & & & - & + & + & & - & - & - & + \\
\hline Water supply & & & & - & + & - & + & + & + & - \\
\hline Infrastructure & & & & & \pm & \pm & + & + & + & - \\
\hline $\begin{array}{l}\text { Shallow geo- } \\
\text { materials }\end{array}$ & & & & & & - & + & + & + & - \\
\hline $\begin{array}{l}\text { Deep geo- } \\
\text { materials }\end{array}$ & & & & & & & - & \pm & \pm & + \\
\hline $\mathrm{CO}_{2}$ storage & & & & & & & & - & - & + \\
\hline Gas storage & & & & & & & & & - & + \\
\hline Water storage & & & & & & & & & & - \\
\hline
\end{tabular}

${ }^{\dagger}$ Type of interaction: subsurface functions will always conflict $(-)$, subsurface functions have potential to conflict $(-)$, subsurface functions almost never conflict $(+)$, subsurface functions are potentially conflicting, but mutual benefits can be achieved through adequate subsurface planning $( \pm)$.

\#Aquifer thermal energy storage.

${ }^{\S}$ Borehole thermal energy system.

\section{CONCLUSIONS}

Given the accelerating construction rate of UTES systems in the Netherlands and Europe, a growing number of systems are expected to be installed in the vicinity of drinking water well fields and other subsurface interests. This clearly indicates that water supply and energy supply are increasingly becoming competitors for subsurface services. Although the risks that UTES can have on drinking water production are broadly known, a comprehensive strategy to manage risks and monitor adverse impacts is currently lacking. The recent recommendations for policy changes in the Netherlands in the water-energy field aim at optimizing the use of the underground for renewable energy production. The lack of a clear and scientifically underpinned risk management strategy implies that potentially unwanted risks might be taken at vulnerable locations such as near well fields used for drinking water production, whereas at other sites, the application of UTES is avoided without proper reasons. This means that the sustainability of UTES as a form of renewable energy is currently not fully understood, and the technology may be compromising the natural resilience of the subsurface environment. We recognize three main issues that should be addressed to secure sustainable application of UTES: Scientific research is required to further elucidate the impacts of UTES on groundwater; cross-sectoral subsurface planning is required to minimize negative conflicts between UTES and other subsurface interests; and EU-wide guidelines and 
standards are required for quality assurance and control when installing UTES systems.

Responses to this article can be read online at: http://www.ecologyandsociety.org/vol16/iss 1/art22/ responses/

\section{Acknowledgments:}

This research was funded by the Joint Research Program of the Dutch drinking water sector (BTO) and the European Commission through the European Cooperation in Science and Technology program. We thank Boris van Breukelen, Nick Gorski, Karen Hussey, and Jamie Pittock for their helpful comments.

\section{LITERATURE CITED}

Appelo, C. A. J., and D. Postma. 2005. Geochemistry, groundwater and pollution. Second edition. Balkema, Leiden, The Netherlands.

Arning, E., M. Kölling, H. D. Schulz, B. Panteleit, and J. Reichling. 2006. Einfluss oberflächennaher Wärmegewinnung auf geochemische Prozesse im Grundwasserleiter. Grundwasser 11(1):27-39.

Avci, C. B. 1992. Flow occurrence between confined aquifers through improperly plugged boreholes. Journal of Hydrology 139(1-4):97-114.

Bobylev, N. 2009. Mainstreaming sustainable development into a city's master plan: a case of urban underground space use. Land Use Policy 26 (4):1128-1137.

Bonte, M., P. J. Stuyfzand, G. van den Berg, and W. A. M. Hijnen. 2011. The effects of aquifer thermal energy storage on groundwater quality and the consequences for drinking water production: a case study from the Netherlands. Water Science and Technology, in press.

Bonte, M., G. van den Berg, and A. M. Wezel. 2008. Bodemenergiesystemen in relatie tot grondwaterbescherming. Bodem 5:22-26.
Brielmann, H., C. Griebler, S. I. Schmidt, R. Michel, and T. Lueders. 2009. Effects of thermal energy discharge on shallow groundwater ecosystems. FEMS Microbiology Ecology 68(3):273-286.

Brons, H. J., J. Griffioen, C. A. J. Appelo, and A. J. B. Zehnder. 1991. (Bio)geochemical reactions in aquifer material from a thermal energy storage site. Water Research 25(6):729-736.

Centraal Bureau voor de Statistiek. 2008. Duurzame energie in Nederland 2007. Centraal Bureau voor de Statistiek, Den Haag, The Netherlands. [online] URL: http://www.cbs.nl/NR/rdonlyres/F1000AA9B444-45A0-91B9-2DDCA9AF237F/0/2007c89pub. pdf.

Chesnaux, R., R. P. Chapuis, and J. W. Molson. 2006. A new method to characterize hydraulic shortcircuits in defective borehole seals. Ground Water 44(5):676-681.

De Vries, J. J. 2007. Groundwater. Pages 295-315 in T. E. Wong, D. A. J. Batjes, and J. de Jager, editors. Geology of the Netherlands. Royal Netherlands Academy of Arts and Sciences, Amsterdam, The Netherlands.

Dufour, F. C. 2000. Groundwater in the Netherlands: facts and figures. Netherlands Institute of Applied Geoscience TNO, Utrecht, The Netherlands.

Evans, D., M. Stephenson, and R. Shaw. 2009. The present and future use of 'land' below ground. Land Use Policy 26(S1):S302-S316.

Ferguson, G. 2006. Potential use of particle tracking in the analysis of low-temperature geothermal developments. Geothermics 35(1):44-58.

Ferguson, G. 2009. Unfinished business in geothermal energy. Ground Water 47(2):167.

Ferguson, G., and A. D. Woodbury. 2006. Observed thermal pollution and post-development simulations of low-temperature geothermal systems in Winnipeg, Canada. Hydrogeology Journal 14 (7):1206-1215.

Ferguson, G., and A. D. Woodbury. 2007. Urban heat island in the subsurface. Geophysical Research Letters 34: L23713. [online] URL: http://www.agu. org/journals/gl/g10723/2007GL032324/. 
Gao, Q., M. Li, M. Yu, J. D. Spitler, and Y. Y. Yan. 2009. Review of development from GSHP to UTES in China and other countries. Renewable and Sustainable Energy Reviews 13(6-7):1383-1394.

Goldscheider, N., D. Hunkeler, and P. Rossi. 2006. Review: microbial biocenoses in pristine aquifers and an assessment of investigative methods. Hydrogeology Journal 14(6):926-941.

Griebler, C., and T. Lueders. 2009. Microbial biodiversity in groundwater ecosystems. Freshwater Biology 54(4):649-677.

Griffioen, J., and C. A. J. Appelo. 1993. Nature and extent of carbonate precipitation during aquifer thermal energy storage. Applied Geochemistry 8 (2):161-176.

Hall, E. K., C. Neuhauser, and J. B. Cotner. 2008. Toward a mechanistic understanding of how natural bacterial communities respond to changes in temperature in aquatic ecosystems. ISME Journal 2(5):471-481.

Holm, T. R., S. J. Eisenreich, H. L. Rosenberg, and N. P. Holm. 1987. Groundwater geochemistry of short-term aquifer thermal energy storage test cycles. Water Resources Research 23(6):1005-1019.

Hoyer, M., J. Hallgren, S. Eisenreich, and R. Sterling. 1994. Field-test results of aquifer thermal energy storage at St. Paul, Minnesota. Journal of Energy Engineering 120(2):67-85.

IF Technology. 2007. Common practice in ATES application, field data of 67 projects. Unpublished report. IF Technology, Arnhem, The Netherlands.

Klotzbücher, T., A. Kappler, K. L. Straub, and S. B. Haderlein. 2007. Biodegradability and groundwater pollutant potential of organic antifreeze liquids used in borehole heat exchangers. Geothermics 36(4):348-361.

Knauss, K. G., and S. A. Copenhaver. 1995. The solubility of $p$-xylene in water as a function of temperature and pressure and calculated thermodynamic quantities. Geochimica et Cosmochimica Acta 59 (12):2443-2448.

Knauss, K. G., M. J. Dibley, R. N. Leif, D. A. Mew, and R. D. Aines. 2000. The aqueous solubility of trichloroethene (TCE) and tetrachloroethene (PCE) as a function of temperature. Applied Geochemistry 15(4):501-512.

Kooi, H. 2008. Spatial variability in subsurface warming over the last three decades; insight from repeated borehole temperature measurements in The Netherlands. Earth and Planetary Science Letters 270(1-2):86-94.

Korom, S. F. 1992. Natural denitrification in the saturated zone: a review. Water Resources Research 28(6):1657-1668.

Lacombe, S., E. A. Sudicky, S. K. Frape, and A. J. A. Unger. 1995. Influence of leaky boreholes on cross-formational groundwater flow and contaminant transport. Water Resources Research 31(8):1871-1882.

Langwaldt, J. H., and J. A. Puhakka. 2000. On-site biological remediation of contaminated groundwater: a review. Environmental Pollution 107(2):187-197.

Mayo, A. L. 2010. Ambient well-bore mixing, aquifer cross-contamination, pumping stress, and water quality from long-screened wells: What is sampled and what is not? Hydrogeology Journal 18 (4):823-837.

Noyes, P. D., M. K. McElwee, H. D. Miller, B. W. Clark, L. A. Van Tiem, K. C. Walcott, K. N. Erwin, and E. D. Levin. 2009. The toxicology of climate change: environmental contaminants in a warming world. Environment International 35(6):971-986.

Philippacopoulos, A. J., and M. L. Berndt. 2001. Influence of debonding in ground heat exchangers used with geothermal heat pumps. Geothermics 30 (5):527-545.

Prommer, H., and P. J. Stuyfzand. 2005. Identification of temperature-dependent water quality changes during a deep well injection experiment in a pyritic aquifer. Environmental Science and Technology 39(7):2200-2209.

Rock, G., and H. Kupfersberger. 2002. Numerical delineation of transient capture zones. Journal of Hydrology 269(3-4):134-149.

Sanner, B., C. Karytsas, D. Mendrinos, and L. Rybach. 2003. Current status of ground source heat pumps and underground thermal energy storage in Europe. Geothermics 32(4-6):579-588. 
Santi, P. M., J. E. McCray, and J. L. Martens. 2006. Investigating cross-contamination of aquifers. Hydrogeology Journal 14(1-2):51-68.

Schijven, J. F., J. H. C. Mülschlegel, S. M. Hassanizadeh, P. F. M. Teunis, and A. M. de Roda Husman. 2006. Determination of protection zones for Dutch groundwater wells against virus contamination - uncertainty and sensitivity analysis. Journal of Water and Health 4(3):297-312.

Schippers, A., and J. Reichling. 2006. Laboruntersuchungen zum Einfluss von Temperaturveränderungen auf die Mikrobiologie des Untergrundes. Grundwasser 11(1):40-45.

Slenders, H. L. A., P. Dols, R. Verburg, and A. J. de Vries. 2010. Sustainable remediation panel: sustainable synergies for the subsurface: combining groundwater energy with remediation. Remediation Journal 20(2):143-153.

Stuyfzand, P. J. 1998. Quality changes upon injection into anoxic aquifers in the Netherlands: evaluation of 11 experiments. Pages 283-291 in J. H. Peters, editor. Artificial recharge of groundwater: proceedings of the third International Symposium on Artificial Recharge of Ground Water (Amsterdam, 1998). A. A. Balkema, Amsterdam, The Netherlands.

Stuyfzand, P. J. 1999. Patterns in groundwater chemistry resulting from groundwater flow. Hydrogeology Journal 7(1):15-27.

Taniguchi, M., and T. Uemura. 2005. Effects of urbanization and groundwater flow on the subsurface temperature in Osaka, Japan. Physics of the Earth and Planetary Interiors 152(4):305-313.

Taskforce WKO. 2009. Groen licht voor bodemenergie. Ministerie van VROM, Den Haag, The Netherlands. [online] URL: http://www.rijksov erheid.nl/documenten-en-publicaties/brochures/200 9/03/01/groen-licht-voor-bodemenergie-advies-taskforcewko.html.

ten Hulscher, T. E. M., and G. Cornelissen. 1996. Effect of temperature on sorption equilibrium and sorption kinetics of organic micropollutants - a review. Chemosphere 32(4):609-626.
Uršej, Š., and B. Kontic. 2007. The role of surface characteristics in directing subsurface spatial planning processes: the case study of a high-speed railway in Slovenia. Tunnelling and Underground Space Technology 22(4):414-432. 